\title{
Relationship between Discussion Activity and Try-Out on Learning Outcomes of Medical Students
}

\author{
Adnyana Putra ${ }^{1, *}$ Made Kurnia Widiastuti Giri ${ }^{1}$ \\ ${ }^{1}$ Medical Education Study Program, Universitas Pendidikan Ganesha, Singaraja , Bali \\ * Corresponding author.Email: adnyanaputra@undiksha.ac.id
}

\begin{abstract}
This study aimed to examine the relationship between the level of discussion activity and the results of try-out with learning outcomes in medical students. The research design used was quantitative observational cross-sectional research. The subjects were students in semesters 1, 3, and 5 from Study Program of Medicine Universitas Pendidikan Ganesha Academic Year 2021/2022. Level of discussion activity was assessed by the discussion score determined by number of responses and questions asked. Try-out variable was taken from the results of try-out carried out by student's organization. Learning outcomes were obtained from final exam score. Data were analysed descriptively. Next step data of learning outcomes on status of try-out (took or didn't take) were compared. On final analysis correlation and regression analysis were determined. About 56 out of 151 subjects were excluded from final step of analysis because they didn't take try-out program. The results showed that the discussion score and try-out score have an effect of $20.1 \%$ $(\mathrm{p}<0.001)$ on learning outcomes. Other results also showed that the final exam scores of students who took the try-out were higher than the students who did not take the try-out (average score $=76.37, \mathrm{SD}=13.28$ vs. average score $=68.78$, $\mathrm{SD}=16.33 ; \mathrm{p}<0.01)$. It can be concluded that discussion process and try-out correlate with learning outcomes.
\end{abstract}

Keywords: Discussion, Try-Out, Learning Outcomes, Medical Student.

\section{INTRODUCTION}

Learning process in medical education in Indonesia is currently more focused and adjusted to the guidelines of the Indonesian Doctor Competency Standards (SKDI). The ultimate goal of this learning process is to increase learning outcomes. One of the learning principles in medical education is student-centred learning. One of the variables that can be used as an indicator of student activity is the level of activity in asking and answering or responding. This activity can also function in assessing student learning processes. However, how this activity level correlates with learning outcomes has not been studied further.

In an effort to improve their learning outcomes, the students have started to carry out a try-out program. This try-out is carried out as one of the student organization programs. However, there are no further studies related to its correlation with learning outcomes. Another interesting thing is that not all students are interested in participating in this try-out program. This can be a review of research related to the effectiveness of try-out program.
Providing feedback is one of many methods of improving learning outcomes. Feedback is important to avoid uncertainty in students, correct errors by students, guide students to choose better learning methods and encourage students to become perfect [1]. Teacher feedback affects the relationship between teachers and students and affects learning outcomes and selfperception [2]. There is a positive relationship between positive feedback and student learning outcomes. Positive feedback also increases students' motivation, self-confidence, and self-efficacy, and students' academic skills. Feedback (both positive and negative) is beneficial in improving students' academic skills and learning outcomes [3]. Feedback can help students recognize their mistakes and work harder to avoid these mistakes in the future [4],[5]. Students from Study Program of Medicine Universitas Pendidikan Ganesha had conducted a try-out program in order to prepare to face the final exam on each block. This try-out program is carried out by student organizations. Contents (questions and answers) in this try-out program were made by students themselves. This try-out program can function as a feedback mechanism. On the other hand, the 
feedback mechanism in this program is less than optimal considering that the results of the try-out are only rough numbers.

The discussion process plays an important role in honing students' critical thinking processes. However, a good the discussion process certainly requires good direction from the discussion facilitator. A good facilitator will direct students to do more critical thinking processes or critical thinking [6]. In one study, it was found that although the discussion was conducted online, the discussion was still able to encourage students to carry out a process of reflection within themselves [7].

Evidence shows that discussions in smaller groups are more effective than discussions in large groups in terms of improving thinking and developing behaviours or attitudes. In addition, the party responsible for group dynamics in the discussion apart from the tutor is also the student themselves. Important skills needed in discussion include asking, listening, responding or giving feedback, and explaining skills. Attention to socio-emotional aspects together with the main task of the group is more important to pay attention to than only to group work. This is because the socio-emotional aspects that occur during the discussion process can affect group dynamics. Therefore, in order to get experience satisfaction in carrying out discussions, students' attention is needed in improving the discussion process [8].

Study on learning biochemistry by medical students found that the type of discussion in the form of small group discussion had an effect on critical thinking processes and problem-solving processes. This can be seen from the results of a significant difference between the results of pre-test and post-test. The majority of students also felt that small group discussions improved the students' learning and memory processes [9]. However, its correlation with learning outcomes in general has not been explored. Based on the results of the study, the performance of student activities in the discussion was not significantly correlated with the critical thinking process [6]. However, the correlation with learning outcomes has not been reviewed directly.

Specifically for learning in block system, results of a block final exams are used as a reference for medical students' learning outcomes [10]. Final exam scores are considered as an appropriate reference when compared to the final score considering that the components of the final exam and the percentage of its contribution to the final score may differ between medical education institutions. In addition, final exams of every block system are carried out at every medical education institution that implements block learning system. In this institution, the final exam was carried out right after the block system had finished its learning program.

\section{METHOD}

This type of research was an observational study with a cross-sectional design. The research was conducted at Study Program of Medicine, Faculty of Medicine, Universitas Pendidikan Ganesha. The population and subjects of this study were students in semesters 1, 3, and 5 of Study Program of Medicine, Faculty of Medicine, Universitas Pendidikan Ganesha academic year $2021 / 2022$. Subject exclusion was carried out when data on one of the variables was not provided.

Discussion activity was determined by student's activities in group discussions in form of number of questions and responses. Try-out variable was determined by student's scores from try-out program carried out by student organizations. The results of tryout were not a factor that counts in the final score. Learning outcomes was determined by student's scores on final exams.

Discussion activity in form of number of questions and answers or responds was obtained from student reports. The results of try-out were taken from the student's score after completing the try-out program. Learning outcomes were taken from first final exam results (not from retest results).

Variables of discussion activity, try-out scores, and learning outcomes were first analysed descriptively. After that, variable of discussion activity and try-out scores were analysed in relation to the variables of learning outcomes through correlation and regression analysis. Quantitative data analysis was performed using SPSS software.

\section{RESULTS AND DISCUSSION}

\subsection{Results}

The total number of subjects was 151 students of which 56 students were excluded from the next step analysis because they did not take part in try-out program. From a total of 151 students, final exam scores were compared between those who took the try-out and those who did not take the try-out according to Table 1.

Table 1. Final Exam Scores on Try-Out Status

\begin{tabular}{|l|c|c|}
\hline \multicolumn{1}{|c|}{ Try-out status } & Yes & No \\
\hline $\mathrm{N}$ & 95 & 56 \\
\hline Mean & 76.37 & 68.78 \\
\hline Std. Deviation & 13.28 & 16.33 \\
\hline Std. Error Mean & 1.36 & 2.18 \\
\hline
\end{tabular}

In table 1, it can be seen that the average final exam score of subjects who took the try-out was greater than that of subjects who did not take the try-out (76.37, $\mathrm{SD}=13.28$ vs $68.78, \mathrm{SD}=16.33)$. This difference was also 
confirmed from the results of further analysis using independent samples test in Table 2. The significant result was obtained at $\mathrm{p}=0.004$ (equal variances not assumed). Thus, it can be concluded that there is a difference in final exam scores between students who take the try-out and students who do not take the try-out where students who take the try-out program have a final exam score that is greater than students who do not take the try-out program.

Descriptive analysis in the next stage was carried out on 95 subjects who took part in the try-out program. Descriptive statistics showed the average for each variable, including: discussion score $(3.91, \mathrm{SD}=2.22)$, try-out score (63.37, $\mathrm{SD}=21.29)$, and final exam score (76.37, $\mathrm{SD}=13.28)$.

The following also showed histogram graphs from Figure 1 to Figure 3 with normal curve lines inserted. It can be seen that in Figure 1 the discussion score variable has a skewness or slope to the left, while in Figure 2 the try-out score variable has a slight slope to the right. In Figure 3 of the histogram of final exam score, one bar gets a fairly large number of frequencies. The results of the Kolmogorov-Smirnov normality test in Table 4 got significance value entirely below 0.05 on all variables. This showed that the distribution of data from the three variables was not normal.

Table 2. Independent samples test results of final exam scores on try-out status

\begin{tabular}{|c|c|c|c|c|c|c|c|c|c|c|}
\hline & \multicolumn{2}{|c|}{ Levene's Test } & \multicolumn{7}{|c|}{$\mathrm{t}$-test for Equality of Means } \\
\hline & & \multirow[t]{2}{*}{$\mathrm{F}$} & \multirow[t]{2}{*}{ Sig. } & \multirow[t]{2}{*}{$\mathrm{t}$} & \multirow[t]{2}{*}{ df } & \multirow[t]{2}{*}{$\begin{array}{l}\text { Sig. }(2- \\
\text { tailed) }\end{array}$} & \multirow[t]{2}{*}{$\begin{array}{c}\text { Mean } \\
\text { Difference }\end{array}$} & \multirow[t]{2}{*}{$\begin{array}{l}\text { Std. Error } \\
\text { Difference }\end{array}$} & \multicolumn{2}{|c|}{$\begin{array}{l}95 \% \text { Confidence } \\
\text { Interval of the } \\
\text { Difference }\end{array}$} \\
\hline & & & & & & & & & Lower & Upper \\
\hline \multirow[t]{2}{*}{$\begin{array}{l}\text { final } \\
\text { exam }\end{array}$} & $\begin{array}{l}\text { Equal variances } \\
\text { assumed }\end{array}$ & .941 & .334 & 3.111 & 149 & .002 & 7.58957 & 2.43950 & 2.76908 & 12.41006 \\
\hline & $\begin{array}{l}\text { Equal variances } \\
\text { not assumed }\end{array}$ & & & 2.950 & 97.530 & .004 & 7.58957 & 2.57277 & 2.48369 & 12.69545 \\
\hline
\end{tabular}

Table 3. Descriptive statistics results

\begin{tabular}{|l|c|c|c|}
\hline & $\begin{array}{c}\text { Discussion } \\
\text { Score }\end{array}$ & $\begin{array}{c}\text { Try- } \\
\text { Out }\end{array}$ & $\begin{array}{c}\text { Final } \\
\text { Exam }\end{array}$ \\
\hline $\mathrm{N}$ & 95 & 95 & 95 \\
\hline Mean & 3.91 & 63.37 & 76.37 \\
\hline $\begin{array}{l}\text { Std. Error of } \\
\text { Mean }\end{array}$ & .23 & 2.18 & 1.36 \\
\hline $\begin{array}{l}\text { Std. } \\
\text { Deviation }\end{array}$ & 2.22 & 21.29 & 13.28 \\
\hline Range & 15.00 & 98.00 & 61.68 \\
\hline Minimum & 1.00 & 2.00 & 32.00 \\
\hline Maximum & 16 & 100 & 93.68 \\
\hline
\end{tabular}

Table 4. Normality test results

\begin{tabular}{|l|r|r|r|}
\hline \multirow{2}{*}{} & \multicolumn{3}{|c|}{ Kolmogorov-Smirnova } \\
\cline { 2 - 4 } & Statistic & df & \multicolumn{1}{c|}{ Sig. } \\
\hline final exam & .128 & 95 & .001 \\
\hline try-out & .146 & 95 & .000 \\
\hline discussion score & .206 & 95 & .000 \\
\hline \multicolumn{4}{|l}{} \\
\hline
\end{tabular}

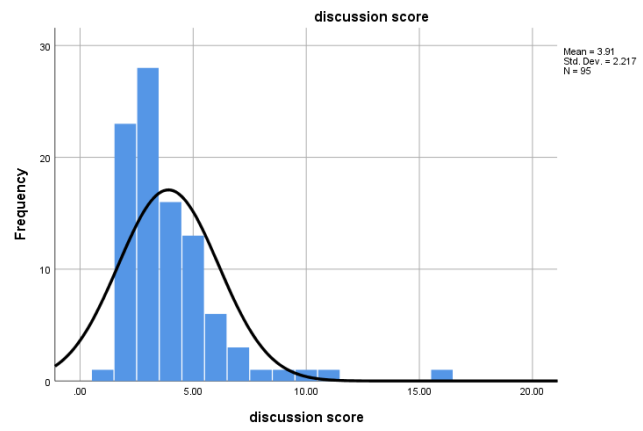

Figure 1. Histogram of discussion score

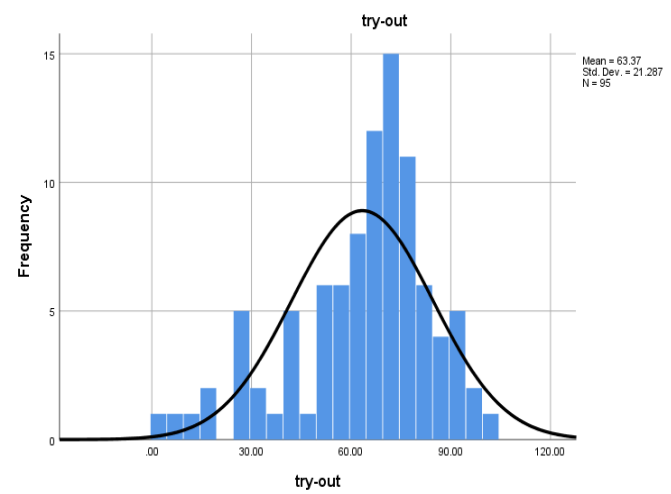

Figure 2. Histogram of try-out score 


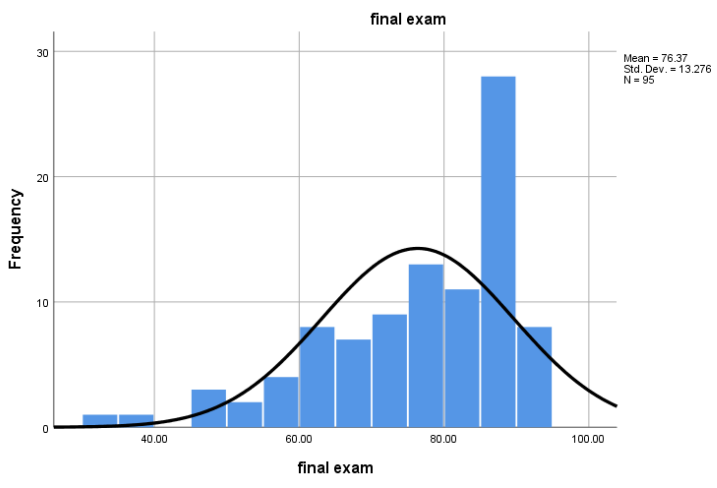

Figure 3. Histogram of Final Exam Score

The test results using Spearman correlation test in Table 5 found that try-out score and discussion score variables had a significant correlation $(<0.001)$ on the final exam score. The results of the linear regression test in Table 7 show that the model made is very significant $(<0.001)$ but the influence of the independent variable (discussion score and try-out) only determines about $20.1 \%$ on final exam score (Table 6). Based on the results of the Spearman correlation (in Table 5) and collinearity statistics (in Table 8) there is no indication of multicollinearity between the discussion score variable and the try-out score variable.

\subsection{Discussion}

The results of this study are in line with the results of other studies, although in a slightly different context. Background in that research is student activities in responding to e-learning learning. Results of that study stated that more frequent learning responses were associated with higher learning outcomes [11]. Good discussion performance requires good preparation in terms of tracing various literature sources and making conclusions. Searching for literature and preparing materials (making conclusions) are two aspects that contribute to performance during discussions, in this case, in the reporting phase. Results of that study found that aspect of making inferences contributed more important than literature search so that the discussion process could-run better [12].
Table 5. Correlation between variables

\begin{tabular}{|c|c|c|c|c|}
\hline & $\begin{array}{l}\text { final } \\
\text { exam }\end{array}$ & try-out & $\begin{array}{c}\text { discussion } \\
\text { score }\end{array}$ \\
\hline \multirow[t]{3}{*}{$\begin{array}{l}\text { final } \\
\text { exam }\end{array}$} & $\begin{array}{l}\text { Correlation } \\
\text { Coefficient }\end{array}$ & 1.000 & $.422^{* *}$ & $.353^{\star \star}$ \\
\hline & Sig. (2-tailed) & . & .000 & .000 \\
\hline & $\mathrm{N}$ & 95 & 95 & 95 \\
\hline \multirow[t]{3}{*}{ try-out } & $\begin{array}{l}\text { Correlation } \\
\text { Coefficient }\end{array}$ & $.422^{* *}$ & 1.000 & .130 \\
\hline & Sig. (2-tailed) & .000 & . & .210 \\
\hline & $\mathrm{N}$ & 95 & 95 & 95 \\
\hline \multirow{3}{*}{$\begin{array}{l}\text { discus } \\
\text { sion } \\
\text { score }\end{array}$} & $\begin{array}{l}\text { Correlation } \\
\text { Coefficient }\end{array}$ & $.353^{* *}$ & .130 & 1.000 \\
\hline & Sig. (2-tailed) & .000 & .210 & \\
\hline & $\mathrm{N}$ & 95 & 95 & 95 \\
\hline
\end{tabular}

Table 6. Correlation analysis

\begin{tabular}{|l|l|l|l|l|}
\hline Model & $R$ & $R$ Square & $\begin{array}{c}\text { Adjusted R } \\
\text { Square }\end{array}$ & $\begin{array}{c}\text { Std. Error of the } \\
\text { Estimate }\end{array}$ \\
\hline 1 & $.448^{a}$ & .201 & .184 & 11.99559 \\
\hline \multicolumn{2}{|l|}{ a. Predictors: (Constant), discussion score, try-out } \\
\hline
\end{tabular}

Table 7. Regression model and its significance

\begin{tabular}{|l|l|r|r|r|r|l|}
\hline \multicolumn{2}{|c|}{ Model } & $\begin{array}{c}\text { Sum of } \\
\text { Squares }\end{array}$ & df & $\begin{array}{c}\text { Mean } \\
\text { Squar } \\
\text { e }\end{array}$ & F & Sig. \\
\hline 1 & Regression & 3330.3 & 2 & 1665.2 & 11.6 & $.000^{\mathrm{b}}$ \\
\cline { 2 - 7 } & Residual & 13238.3 & 92 & 143.9 & & \\
\cline { 2 - 7 } & Total & 16568.6 & 94 & & & \\
\hline \\
a. Dependent Variable: final exam \\
\hline
\end{tabular}

Table 8. Linear regression analysis and collinearity statistics

\begin{tabular}{|c|c|c|c|c|c|c|c|c|}
\hline & \multirow[t]{2}{*}{ Model } & \multicolumn{2}{|c|}{ Unstandardized Coefficients } & \multirow{2}{*}{$\begin{array}{c}\begin{array}{c}\text { Standardized } \\
\text { Coefficients }\end{array} \\
\text { Beta }\end{array}$} & \multirow[t]{2}{*}{$\mathrm{t}$} & \multirow[t]{2}{*}{ Sig. } & \multicolumn{2}{|c|}{$\begin{array}{l}\text { Collinearity } \\
\text { Statistics }\end{array}$} \\
\hline & & $B$ & Std. Error & & & & Tolerance & VIF \\
\hline \multirow[t]{3}{*}{1} & (Constant) & 56.869 & 4.238 & & 13.419 & .000 & & \\
\hline & try-out & .233 & .059 & .373 & 3.964 & .000 & .982 & 1.019 \\
\hline & discussion score & 1.219 & .563 & .204 & 2.165 & .033 & .982 & 1.019 \\
\hline
\end{tabular}


Research has shown that discussion method is better than conventional method in improving learning outcomes. Research on midwifery and nursing students obtained significant results where learning outcomes scores were higher when using the discussion method than using the lecture method (in this case it is interpreted as a conventional method). Results of the study also found that student satisfaction scores did not differ between the two types of methods [13].

However, other studies may show different results. Learning through discussion is considered more prominent and effective than learning through lectures. This can be seen from the higher quiz scores on the subject with the discussion method. However, the next result of this study found that the final exam scores were not significantly different between discussion method and lecture method $(67 \%$ vs. $65 \%, \mathrm{p}=0.19)$. This study concluded that the absence of this significant difference in the final exam scores was probably due to deficiencies in question design and more emphasis on memorized teaching materials [14]. In our study, discussion scores were shown to be significantly related to final exam scores.

Various studies have proven the various benefits or effects of the discussion method. Based on research on student perceptions of the characteristics of effective discussion in problem-based learning (PBL), four characteristics of effective discussion were found: asking, giving and receiving explanations, integrating and applying knowledge, discussing differences in content, and guiding and supervising content and group process during discussion. Integrating and applying knowledge includes patterning, linking, and inferring information and providing practical examples. Discussing different opinions includes discussing various literary sources and their contradictions. The main learning effects mentioned by students include retention, understanding, integration, and application of knowledge. The introduction of PBL to students and tutors should include training in open but focused questioning, supporting explanations with arguments, and dealing with content-related conflicts. Tutors must be trained to provide personal and effective feedback. Likewise, collaborative knowledge (in this case manifested in form of a concept map) needs to be created [15]. Results of study stated that group discussions could improve students' communication skills [16]. The results also showed that most respondents have opinion that small group discussions build an interactive, innovative, and friendly atmosphere between students and lecturers. Small group discussions awaken students' thinking processes and improve their ability to communicate. In this process the gap between lecturers and students is minimized. Small group discussions provide opportunities for students to speak in front of their friends [17]. Ability to store or use information while learning is in progress can be better if there is an elaboration on the source of learning materials. Ability to activate knowledge in long-term memory and can directly use it depends on the contextual situation [18]. This ability can be honed in the discussion process.

However, there are several factors that can be the obstacles for students in the discussion process. Results of study focused on discussion sessions found that there were a number of factors that influenced student's behaviour to speak or not during discussions. Some factors that can be important points include: anxious to speak without any prior background knowledge, only speaking if students feel it is correct, not daring to speak because they are considered to have less knowledge, not daring to challenge their own colleagues, still assuming the tutor as the source of information, consider that tutors have higher status so they don't dare to fight tutors, focus is directed only on discussion sessions that are considered important for exams, and are reluctant to share information [19]. In this study, it can be seen that the average discussion score was 3.91 and the histogram graph showed that distribution of discussion scores in areas above the average showed a wider distribution than in areas below the average. This showed that only a small proportion of students were seen to be very active. Most of the other students were predicted to experience obstacles in the discussion process.

Role of the tutor is very crucial in the discussion process. The tutor's skill is considered as an unplanned variable in PBL. If students are not given the freedom to express their opinion or learn according to their wishes, or students are not guided in logical thinking processes or use various learning resources, then learning objectives will be difficult to achieve [20]. The results of the study found that although a good tutor does not necessarily come from an expert in related field, the data showed that tutors with expertise in the topic of discussion were able to work more effectively. It was explained that skills were not primary but that expertise could help the tutor determine when the discussion was incoherent and help the tutor raise questions that could initiate discussion. The study also found that the length of experience of the tutor had no effect on his/her performance [21].

There are several other factors that can affect learning outcomes. A study of medical students found that selfdirected learning readiness (SDLR) had an effect on student learning achievement. There is a tendency that students with high SDLR scores tend to get high achievement or learning outcomes as well. However, other findings also found that there were students with high SDLR scores but low learning achievements and students with moderate SDLR scores with high learning achievements [22]. This result is possible because there are various factors (both internal and external from students) that affect learning outcomes. However, it can also be a factor that is thought to have an effect on learning outcomes logically, but research showed that it 
didn't show significant results. One study found that the learning style of medical students had no significant effect on learning outcomes [23]. Another factor that influences learning outcomes is the learning environment. During pandemic, the most prominent learning environment is through online learning. Based on the study, it was found that asynchronous online lecture videos are still able to keep students at a high level of learning outcomes [24].

\section{CONCLUSION}

Based on the results and discussion of our study, it can be concluded that discussion activity and try-out (participation or scores) affect learning outcomes on medical students. Further experimental research is needed regarding participation in try-out programs so that the effect of this participation on learning outcomes can be seen more clearly.

\section{AUTHORS' CONTRIBUTIONS}

Author 1 plays a role in making proposals, data analysis, and articles. Author 2 has supported data retrieval, data tabulation, and article correction.

\section{ACKNOWLEDGMENTS}

The acknowledgment is given to students of semesters 1, 3, and 5 from Study Program of Medicine, Universitas Pendidikan Ganesha Education academic year 2021/2022 for their contribution in providing research data. The acknowledgments are also addressed to the Faculty of Medicine, Universitas Pendidikan Ganesha and Ministry of Education, Culture, Research, and Higher Education, the Republic of Indonesia for providing the place for research and for funding this research.

\section{REFERENCES}

[1] S. Shrivastava, R. B. Lal, and P. S. S. J. Ramasamy, "Effective Feedback: An Indispensable Tool for Improvement in Quality of Medical Education," J. Pedagog. Dev., pp. $12-20$.

[2] A. Pankonin and R. Myers, Teachers' Use of Positive and Negative Feedback: Implications for Student Behavior. Opus Spring.

[3] A. Ani, "Positive Feedback Improves Students' Psychological and Physical Learning Outcomes," Indones. J. Educ. Stud., vol. 22, no. 2, pp. 134-143.

[4] D. Cole, "Constructive Criticism: The Role of Student-Faculty Interactions on African American and Hispanic Students' Educational Gains," J. Coll. Stud. Dev., pp. 587-605.
[5] A. Fishbach and T. E. S. R. Finkelstein, "How Positive and Negative Feedback Motivate Goal Pursuit," Soc. Personal. Psychol. Compass, pp. 517-530.

[6] P. J. Foster, "Clinical Discussion Groups: Verbal Participation and Outcomes," J. Med. Educ., vol. 56, pp. 831-838.

[7] M. Furnari, "Medical students' reflections in online discussions-does teacher facilitation matter?," in Rhetoric and Reality: Critical perspectives on educational technology. Proceedings ascilite Dunedin, pp. 574-578.

[8] S. Edmunds and G. Brown, "Effective Small Group Learning," AMEE Guid., vol. 32, no. 48, pp. 715-26.

[9] D. S. C. R. Wilma, D. R. Suresh, and M. V Chandrakala, "Evaluation of Small Group Discussion as A Teaching Learning Method in Biochemistry for First Year MBBS Students: A Pilot Study," South East Asian J. Med. Educ., vol. 8, no. 2, pp. 43-47.

[10] A. A. J. Sukamto and S. Muthmainah, "Estimasi Volume Otak Berhubungan Dengan Prestasi Belajar Pada Mahasiswa Fakultas Kedokteran Universitas Sebelas Maret," Nexus Pendidik. Kedokt. dan Kesehat., vol. 5, no. 1, pp. 12-19.

[11] K. Romanov and A. Nevgi, "Student Activity and Learning Outcomes in A Virtual Learning Environment," Learn. Env. Res, vol. 11, pp. 153162, doi: 10.1007/s10984-008-9038-3.

[12] M. M. Hurk, D. H. J. M. Dolmans, I. H. A. P. Wolfhagen, A. M. M. Muijtjens, and C. P. M. Vleuten, "Impact of Individual Study on Tutorial Group Discussion," Teach. Learn. Med., vol. 11, no. 4, pp. 196-201, doi: 10.1207/S15328015TLM110403.

[13] M. Safari, B. Y. Panah, H. Ghafarian, and S. Y. Panah, "Comparing the Effect of Lecture and Discussion Methods on Students' Learning and Satisfaction," Iran. J. Med. Educ., vol. 6, no. 1(15, pp. 59-63, [Online]. Available: https://www.sid.ir/en/journal/ViewPaper.aspx?i $\mathrm{d}=49297$.

[14] M. Mahram, B. Mahram, and S. N. Mousavinasab, "Comparison Between the Effect of Teaching Through Student-Based Group Discussion and Lecture on Learning in Medical Students," Strides Dev. Med. Educ., vol. 5, no. 2, pp. 71-79.

[15] A. J. S. F. Visschers-Pleijers, J. A. Jacobs, D. H. J. M. Dolmans, W. S. Grave, I. H. A. P. Wolfhagen, and C. P. M. Vleuten, "Student Perceptions About the Characteristics of an Effective Discussion During the Reporting Phase in Problem-Based Learning," Med. Educ., vol. 
40, pp. 924-931, doi: 10.1111/j.13652929.2006.02548.x.

[16] N. Baghcheghi, H. Kouhestani, and K. Rezaei, "Comparison of The Effect of Teaching Through Lecture and Group Discussion on Nursing Students' Communication Skills With Patients," Iran. J. Med. Educ., vol. 10, no. 3, pp. 211-218.

[17] N. Annamalai, R. Manivel, and R. Palanisamy, "Small Group Discussion: Students Perspectives," Int J Appl Basic Med Res, vol. 5, no. 1, pp. 18-20, doi: 10.4103/2229516 X.162257.

[18] H. G. Schmidt, "Foundations of Problem-Based Learning: Some Explanatory Notes," Med. Educ., vol. 27, pp. 422-432.

[19] J. M. Frambach, E. W. Driessen, P. Beh, P. M. Cees, and P. M. Vleuten, "Quiet or Questioning? Students' Discussion Behaviors in StudentCentered Education Across Cultures," Stud. High. Educ., vol. 39, no. 6, pp. 1001-1021, doi: 10.1080/03075079.2012.754865.

[20] H. S. Barrows, "A Taxonomy of Problem-Based Learning Methods," Med. Educ., vol. 20, pp.
$481-486$.

[21] M. L. Volder, "Discussion Groups and Their Tutors: Relationships Between Tutor Characteristics and Tutor Functioning," High. Educ., vol. 11, pp. 269-271, doi: 10.1007/BF00155618.

[22] N. A. Lestari, U. Hasanah, and R. W. Alibasjah, "The effect of self-directed learning readiness (SDLR) and learning approach toward medical student achievement," Proc. Int. Conf. Appl. Sci. Heal., no. 4, pp. 222-227.

[23] S. C. Liew, J. Sidhu, and A. Barua, "The Relationship Between Learning Preferences (Styles and Approaches) and Learning Outcomes Among Pre-Clinical Undergraduate Medical Students," BMC Med. Educ., pp. 15-44.

[24] R. C. Choe et al., "Student Satisfaction and Learning Outcomes in Asynchronous Online Lecture Videos," CBE-Life Sci. Educ., vol. 18, no. 55, pp. 1-14. 